\title{
NATO science programme feels the heat over funds and goals
}

[PARIS \& MONTREAL] The North Atlantic Treaty Organization (NATO) science programme plunged into crisis last week when the NATO council, prompted by Canada, failed to approve next year's budget for the programme. The crisis stems from growing pressures on NATO finances caused by its enlargement in Eastern Europe and internal conflict about the goals of the science programme - indeed, whether it is still required at all.

The programme was set up in 1957 as part of NATO's bid to strengthen security and cooperation among its 16 member states. It spends around $\$ 40$ million a year on a series of basic and applied research programmes that have attracted the support of some of the best scientists in NATO countries. NATO fellowships, Collaborative Research Grants familiar and well-respected.

The crisis has been precipitated by the costs of the enlargement of NATO, which the Pentagon estimates at $\$ 27$ to $\$ 35$ billion over 12 years. This includes a $\$ 5$ billion increase in NATO's own budget over 10 years, on top of the current $\$ 1.8$ billion that it already spends on administration and other activities each year.

The science programme is part of NATO's civil budget, which is much smaller than its military budget. One senior NATO and Advanced Study Institutes have become

official says the programme is particularly vulnerable because funding comes from foreign ministries, for whom science is not a high priority.

The tensions came to a head earlier this month, when Canada unilaterally decided to stop its funding for the science programme. Rodney Moore, a spokesman for the Department of External Affairs, says the decision was taken not only for budgetary reasons but also because Canada felt that the programme was no longer needed to strengthen cooperation among NATO partners.

Cuts in the science programme are also favoured by the United States, Britain and

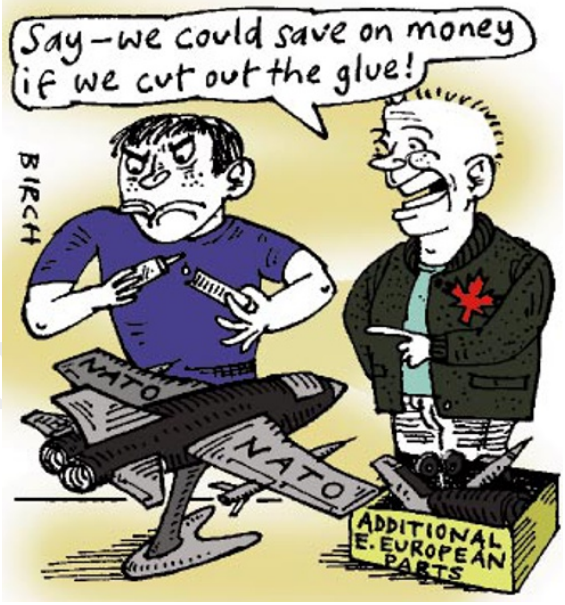

\section{US carbon emissions forecast to rocket}

[WASHINGTON] Carbon emissions in the United States will soar to a level more than one-third higher than that in 1990 by 2010 if current trends continue, according to new official projections. The projections indicate that it will be more difficult than previously forecast to return emissions even to their 1990 level by 2010, let alone to achieve a large reduction, as many countries are demanding should be agreed at the Kyoto meeting on climate change next month (see also page 209 and Briefing, page 215.)

The Energy Information Administration (EIA), an independent statistical agency inside the US Department of Energy, announced last week that, under current best projections of economic growth and energy prices, carbon emissions are forecast to exceed 1990 levels by 34 per cent by 2010 and by 45 per cent by 2020 .

The projection for 2010 is five per cent higher than the agency estimated a year ago, chiefly because of continuing strong economic growth combined with lower prices for energy, especially electricity. The new data suggest it would be even tougher than expected for the United States to meet the target of reducing greenhouse-gas emission to the 1990 level by 2008-2012, which it will take to the Kyoto meeting.

The Clinton administration has already identified the pending restructuring of the US electricity industry as a key opportunity for changes that will reduce carbon emissions. But the EIA projects that restructuring will actually increase emissions by cutting electricity costs, and therefore raising consumption. It will also slow the growth of renewable energy sources of electricity.

The EIA also points out that the 44-point Climate Change Action Plan, which the Clinton administration introduced in 1993 with the aim of stabilizing greenhouse-gas emissions at 1990 levels by the year 2000, has failed to have the desired effect, and expects emissions to overshoot that goal by 17 per cent.

Colin Macilwain the Netherlands, whereas France and Spain would like funding to be maintained at current levels. There are also deep differences over strategy.

Over the past five years, the share of the science programme assigned to supporting cooperation with Eastern Europe and Russia has grown from 5 per cent to almost half. Many NATO countries, including Canada, the United States, France and Britain, would like to see this increase further - one of Canada's stated reasons for its withdrawal was what it claimed was lack of progress in orienting the programme to this goal. But this idea is opposed by smaller countries such as Portugal and Turkey, which would lose out.

Attempts to align the goals of the science programme more closely with diplomatic imperatives received strong support in a recent review of the programme by an independent panel, chaired by Roland Schmitt, a physicist and former head of General Electric's research centre in Schenectady, New York, and including seven other leading researchers. Collaboration with NATO's 24 'cooperation partner' countries in Eastern Europe and defence-related research should be priorities, the panel concluded.

Speaking before the North Atlantic Council in Brussels earlier this month, Schmitt said that the challenge of enlargement in terms of science was as great as that which led to the programme's creation in the first place. "Failure to respond at this moment in time will be tragic, while responding with vision will be seen as a historic response to a unique but transient opportunity," he said.

Science provided a relatively uncontroversial means of underpinning diplomatic goals and tackling security issues such as disarmament and the threat of biological weapons, Schmitt said. He added that NATO had an important role to play in preventing the decline of science in Eastern Europe by maintaining and creating international links. This would "enhance the security of Europe as a whole".

Defending the emphasis on "outreach", Schmitt said it was "with great reluctance" that the review panel recommended that money for this should come from cuts in the intra-alliance programme, given that the science budget would not be increased.

NATO officials hope that Canada can be persuaded to change its position, and that support for the science programme can be mustered. "Discussions are quite heated at the moment, but we hope to get consensus," says one official. DeclanButler \& DavidSpurgeon 